\title{
TINDAK TINDAK PRAGMATIK ANAK USIA PRASEKOLAH DWIBAHASAWAN JAWA-INDONESIA
}

\author{
Mukaromah \\ FKIP Universitas Islam Malang \\ email: mukaromah@yahoo.com
}

\begin{abstract}
This study aims to investigate speech acts in Indonesian uttered by Indonesian-Javanese bilingual preschoolers. The study employed the qualitative approach. The theories employed were theories on pragmatics and language acquisition. The research subjects were Indonesian-Javanese bilingual preschoolers. The researcher was the key instrument. The data were collected through observations, field notes, and recording. The data were analyzed by using the discursive technique. The results of the study show forms of preschoolers' pragmatic competence acquisition. The forms include pragmatic aspects in the utterances in the communication in accordance with the context of use. The pragmatic aspects comprise deixis, presupposition, speech implicature, and conversation rules.
\end{abstract}

Keywords: pragmatics, young learner, language acquisition

\section{PENDAHULUAN}

Lingkungan sosial berperan besar terhadap pemerolehan bahasa anak. Lingkungan sosial yang berbeda-beda, seperti perbedaan faktor budaya, sosial ekonomi orang tua, lokasi atau tempat tinggal, dan lingkungan bermain, mengakibatkan anak memperoleh masukan yang berbeda-beda dalam pemerolehan bahasanya. Dalam lingkungan sosial tersebut, menurut Burt dan Heidi (1991), anak berlatih menggunakan kaidah-kaidah berbahasa sesuai dengan konteks komunikasi, misalnya memperhatikan status dan peran mitra tutur, topik perbicaraan, latar penuturan, variasi kode yang digunakan, dan sebagainya.

Berdasarkan uraian tersebut, dalam penelitian ini, fenomena pemerolehan bahasa anak dipandang sebagai fakta kebahasaan sekaligus fakta sosial. Fakta kebahasaan berhubungan dengan bentuk verbal dan variasi bentuk verbal kompetensi berbahasa, khususnya kompetensi pragmatik, yang diperoleh anak. Adapun fakta sosial berhubung- an dengan sistem penggunaan bahasa dalam situasi atau latar, topik, dan hubungan antarmitra tutur, serta berhubungan dengan nilai-nilai budaya anak yang melatarbelakangi penggunaan bentuk bahasa dalam interaksi berbagai mitra tutur.

Proses penguasaan terhadap dua bahasa atau lebih oleh anak tidak terlepas dengan latar belakang budaya yang mewadahi kedua bahasa tersebut. Menurut Saville-Troike (1980) dan Nababan (1984), tata cara berkomunikasi tidak terlepas dari kerangka sosial budaya tertentu. Dengan demikian, pada proses pemerolehan bahasa anak dwibahasawan Jawa-Indonesia secara bersamaan mereka menguasai dua budaya yang melatari kedua bahasa tersebut. Mereka akan mempelajari norma sosial kedua bahasa tersebut. Penguasaan terhadap norma sosial bahasa ditunjukkan melalui perilaku berbahasa anak yang berterima bagi masyarakat sekitarnya. Pada proses pemerolehannya BJ dipelajari dengan kaidah penggunaan yang di- 
atur berdasarkan adat-istiadat dan tata nilai budaya yang dianut oleh masyarakat Jawa. Demikian juga pada proses pemerolehan $\mathrm{BI}$, anak dituntut untuk menggunakan kaidah-kaidah yang berlaku dalam BI. Kemampuan anak menggunakan kaidah-kaidah BJ dan BI tersebut mencerminkan kemampuan anak dalam menggunakan adat-istiadat dan sikap anak terhadap tata nilai budaya yang melatari kedua bahasa tersebut.

Penelitian ini difokuskan pada pengkajian tentang bagaimanakah kompetensi pragmatik berbahasa Indonesia (BI) anak prasekolah dwibahasawan Jawa-Indonesia? Secara khusus, dalam penelitian ini dikaji tentang beberapa hal sebagai berikut (1) bagaimanakah dieksis yang diperoleh anak usia prasekolah dwibahasawan Jawa-Indonesia? (2) bagaimanakah praanggapan yang diperoleh anak usia prasekolah dwibahasawan Jawa-Indonesia? (3) bagaimanakah implikatur yang diperoleh anak usia prasekolah dwibahasawan Jawa-Indonesia? dan (4) bagaimakah aturan percakapan yang diperoleh anak usia prasekolah dwibahasawan Jawa-Indonesia?

Pengkajian pemerolehan kompetensi pragmatik pada anak prasekolah dalam penelitian ini didasari oleh pendapat Clark dan Clark (1977:329) bahwa pada usia kurang lebih lima tahun proses perkembangan bahasa anak sudah menyerupai orang dewasa, baik aspek bunyi, bentuk kata, struktur kalimat, maupun organisasi wacana. Adapun menurut (Ninio, 1996) tahap pengembangan pragmatik anak terjadi setelah usia anak lebih dari enam tahun ( $>6$ th). Penelitian ini menggunakan subjek anak prasekolah yang berusia $4-5$ tahun untuk mengetahui kekhasan kompetensi pragmatik anak sebelum kompetensi berbahasa mereka menyerupai orang dewasa dan sebelum masa pengembangan pragmatiknya berlangsung.
Dalam sebuah keluarga anak memperoleh bahasa dari orangtua melalui proses secara alami. Tujuan utama proses ini adalah penguasaan bahasa yang terkait dengan fungsi komunikatif, dan bukan untuk menguasai bentuk bahasa secara formal. Penguasaan kosa kata dan struktur saja menjadi kurang bermakna bila kosakata dan struktur tersebut tidak dapat dimanfaatkan untuk mengungkapkan dan memahami maksud antara penutur dan mitra tuturnya. Anak diharapkan dapat berkomunikasi dengan menggunakan bahasa tertentu sesuai dengan faktor-faktor penentu dalam komunikasi secara nyata. Faktor-faktor penentu tersebut adalah partisipan, latar, tujuan, topik, nada atau cara, norma interaksi, dan ragam bahasa yang digunakan (Hymes, 1975). Kemampuan menggunakan bahasa secara demikian disebut kompetensi pragmatik (Nababan, 1987). Berkaitan dengan hal tersebut, Fraser (1980) mengemukakan bahwa istilah kompetensi pragmatik (pragmatic competence) digunakan secara analog dengan istilah kompetensi linguistik (linguistic competence) seperti yang dikemukakan Chomsky. Kompetensi linguistik diartikan sebagai pengetahuan yang dipersyaratkan untuk memahami kalimat-kalimat, sedangkan kompetensi pragmatik adalah pengetahuan yang dipersyaratkan untuk menentukan apa maksud suatu kalimat diujarkan dalam cara tertentu dan dalam konteks tertentu.

Bentuk-bentuk pemerolehan bahasa anak terealisasi pada tindak tutur dalam komunikasi, dan lebih khusus lagi terwujud pada kemampuan ilokusi. Kemampuan ilokusi tersebut tampak pada tuturan anak dengan ciri-ciri tertentu. Tindak tutur inilah yang merupakan bentuk nyata dari penggunaan bahasa dalam berbagai peristiwa komunikasi. Terkait dengan hal ini, kajian dalam penelitian ini difokuskan pada 
bentuk kompetensi pragmatik BI yang diperoleh anak, yang meliputi dieksis, praanggapan, implikatur, inferensi, inferensi, dan aturan percakapan dalam berbagai tindak tutur anak prasekolah dwibahasawan Jawa-Indonesia.

Pengkajian terhadap kompetensi pragmatik dalam tindak tutur ini didasarkan pada pandangan bahwa unit komunikasi bahasa bukan berupa simbol, kata, atau kalimat, tetapi lebih merupakan pemroduksian simbol, kata, atau kalimat yang terealisasi dalam tindak tutur (Mey, 1993:110; Schiffrin, 1994:54; dan Duranti, 2000:45). Pertimbangan lain perlunya pengkajian kompetensi pragmatik anak pada tindak tutur ini adalah adanya fakta bahwa anak-anak prasekolah yang dijadikan subjek penelitian ini telah mempunyai kemampuan untuk memproduksi tuturan secara lengkap (Levinson, 1992).

\section{METODE}

Untuk mencapai tujuan penelitian, dalam penelitian ini digunakan pendekatan kualitatif. Ancangan teori yang digunakan dalam penelitian ini adalah teori pragmatik dan teori pemerolehan bahasa. Data penelitian ini terdiri atas tuturan anak prasekolah dwibahasawan Jawa-Indonesia yang diujarkan dalam interaksi dengan berbagai mitra tutur, dan catatan lapangan tentang konteks komunikasi yang diperoleh dari hasil pengamatan peneliti di lapangan. Subjek penelitian ini adalah penutur bahasa anak prasekolah dwibahasawan JawaIndonesia.

Dalam penelitian ini peneliti berlaku sebagai instrumen kunci. Oleh karena, data dalam penelitian ini berupa perilaku manusia yang hanya dapat dipahami melalui interaksi antara peneliti dengan subjek dan faktor-faktor yang berperan dalam kegiatan berkomunikasi subjek. Sedangkan instrumen tam- bahan yang digunakan adalah pedoman pengamatan dan alat bantu pengamatan, yaitu perekam elektronik (tape recorder) serta alat pencatatan lapangan.

Teknik pengumpulan data yang digunakan adalah teknik pengamatan. Teknik pengamatan dilakukan baik dengan partisipasi maupun nonpartisipasi. Pengamatan difokuskan pada kegiatan anak prasekolah dwibahasawan Jawa-Indonesia dalam melakukan interaksi verbal dengan berbagai mitra tutur. Teknik pengamatan dilengkapi dengan pencatatan lapangan dan perekaman.

Pengumpulan data di lapangan yang dilakukan melalui pengamatan sangat memperhatikan latar dan konteksnya. Maksudnya adalah suatu peristiwa atau kasus yang sedang diamati diperhatikan dan dicatat pula dalam kondisi bagaimana, tempat dan waktu seperti apa, di mana, dan dalam suanana bagaimana. Wawancara terhadap orangtua juga dilakukan untuk kepentingan trianggualasi data hasil perekaman dan cacatan pengamatan lapangan.

Untuk mencapai tujuan penelitian ini, berbagai data pendukung penelitian ini dianalisis berdasarkan teknik analisis diskursif. Teknik analisis diskursif dikembangkan dengan tujuan untuk menerangkan suatu fenomena bahasa secara mendalam dengan memanfaatkan fakta kebahasaan tertentu yang menjadi sasaran penelitian. Dengan menggunakan teknik analisis ini peneliti dapat memiliki kesempatan yang leluasa untuk melakukan interpretasi terhadap rekaman percakapan yang diperoleh dari subjek. Sejalan dengan teknik analisis ini, alur kegiatan analisis terdiri atas beberapa langkah yang terjadi secara bersamaan, yaitu seleksi data, pengkodean data, pengklasifikasian data, penyajian data, dan penarikan kesimpulan. 


\section{HASIL DAN PEMBAHASAN}

Bentuk Pemerolehan Dieksis Anak Usia Prasekolah

Bentuk pemerolehan dieksis tampak pada penggunaan dieksis berdasarkan empat dimensi yang terlibat dalam suatu dieksis, yaitu temporal, spasial, sosial, dan wacana. Menurut Dardjowijojo (2000) terdapat tiga masalah dalam pemerolehan kata-kata dieksis, yaitu titik tolak referensi, referensi yang bergeser, dan batas pergeseran. Titik tolak referensi umumnya adalah pembicara, sehingga kata seperti di sini merujuk pada entitas yang dekat dengan pembicara. Anak harus memahami bahwa rujukan ini sebenarnya mengandung dua prinsip, yaitu pembicara dan jarak. Dalam komunikasi, pembicara sebagai persona pertama seringkali bergeser dari satu ke yang lain sehingga batasnya menjadi kabur. Kekaburan penggunaan dieksis pada anak tampak pada tuturan beri-kut.

Tuturan (01)

Labda : Mbak Labda kan sudah tidur ke situ. Katanya kamu mau nginap ke sini, ke rumah mbak Labda?

Nana : Iya, sama mama, kalo mama libur nginap ke sini.

Konteks : (1) peristiwa tutur: Nana berbincang-bincang dengan sepupunya melalui telepon; (2) tempat: ruang keluarga; (3) waktu: siang hari; (4) tujuan: menjelaskan suatu tempat dengan dieksis ke sini dan ke situ; (5) mitra tutur: kakak sepupunya; dan (6) situasi: santai, akrab.

Tuturan tersebut terjadi antara Nana (4 tahun) dengan kakak sepupunya Labda (10 tahun) melalui telepon. Tampaknya, Nana masih kabur dengan penggunaan kata ke sini dan ke sana seperti kakak sepupunya yang telah dapat menggunakannya secara tepat. Kata ke sini yang mestinya merujuk pada entitas yang dekat dengan penutur digunakan untuk merujuk pada entitas yang dekat dengan mitra tuturnya. Kekaburan ini dimungkinkan juga karena tuturan sebelumnya adalah Mbak Labda kan sudah tidurkesitu. Katanyakamu maunginapkesini, ke rumah mbak Labda, yang menunjukkan bahwa kata ke situ merujuk jarak yang dekat dengan dirinya dan kata ke sini merujuk jarak yang dekat dengan mitra tuturnya sehingga ketika ia berlaku sebagai penutur juga menggunakan kata ke sini untuk merujuk jarak yang dekat dengan mitra tuturnya, yang mestinya menggunakan ke sana.

Bentuk lain kekaburan anak terhadap penggunaan dieksis ini juga berlaku untuk macam dieksis yang lain, yang tampak pada tuturan berikut.

Tuturan (02)

Mama : Mama mau pergi sebentar, kamu di rumah saja ya. Kan ada mbah. Masak Mbah di sini kamu tinggal pergi?

(Tiba-tiba Karinda memeluk neneknya yang sedang sholat dari belakang punggungnya)

Karinda : Mbah, kamu tadi saya kira nggak mbaca Mbah. Tak dengarkan ternyata mbaca ya, pelanpelan.

Konteks : (1) peristiwa tutur: Karinda berbincang-bincang dengan ibunya; (2) tempat: ruang keluarga; (3) waktu: siang hari; (4) tujuan: menyatakan fakta dengan dieksis kamu sebagai bentuk sapaan nenek; (5) mitra tutur: ibu dan nenek; dan (6) situasi: santai, akrab.

Penggunaan kata kamu untuk orang yang lebih tua atau dihormati tentunya kurang tepat. Akan tetapi, itulah yang dilakukan oleh Karinda (4 tahun). Kata ganti kamu digunakan untuk 
merujuk persona kedua. Itulah yang dipahami oleh Karinda, seperti yang dilakukan ibunya dalam tuturan tersebut, juga kemungkinan dalam peristiwa tutur yang lain. Dalam kasus ini, anak melakukan generalisasi berlebihan (overgeneralization) dengan menggunakan kamu untuk merujuk semua persona kedua, tidak terkecuali neneknya. Penggunaan kata kamu untuk merujuk orang yang lebih tua, terlebih-lebih orangtua atau kakek-neneknya, tidak lazim terjadi. Penutur dwibahasawan Jawa-Indonesia untuk merujuk orang yang lebih tua dan dihormati dalam hal ini nenek, biasanya menggunakan sebutan mbah atau mbah putri dan eyang atau eyang putri.

Bentuk penggunaan dieksis oleh anak usia prasekolah juga tampak pada tuturan subjek berikut ini.

Tuturan (03)

Dafa : Lha kok malem-malem ini, kok ada kereta?

Ibu : Kan ada lampunya. Kalau nggak ada lampunya gimana kalau nabrak?

Dafa : Kalau siang?

Ibu : Ya, kereta ada yang jalan malem, ada siang.

Dafa : Paknya yang nyetir... apa namanya?

Ibu : Yang nyetir kereta? Masinis.

Dafa : Pak masinisnya nggak bobok?

Ibu : Ya gantian. Paknya yang satu bobok, yang satu nyetir, gantian. Kalo capek ganti lagi.

Dafa : Ganti-ganti terus.

Ibu : He eh.

Dafa : Lho masak itu sama dengan yang taknaiki?

Ibu : Iya.

Dafa : Lho Argo Bromo itu kan bagusan dari kereta yang panjang sekali?

Ibu : Iya. Argo Bromo itu kan bagus.

Dafa : Tapi ada kereta lain kan jelek. Ibu : Iya yang kereta biasa. Yang dulu dinaiki mbak Tutik itu, yang parkir.

Dafa : Masak kereta ada yang parkir?

Ibu : Yang nggak jalan, yang nunggu penumpang itu.

Dafa : Yang Mbak Tutik naiki itu?

Ibu : Iya. Nunggu penumpang.

Dafa : Berarti itu banteran Argro Bromo?

Ibu : Argo Bromo.

Konteks : (1) peristiwa tutur: Dafa berbincang-bincang dengan ibunya tentu tentang kereta api; (2) tempat: ruang keluarga; (3) waktu: siang hari; (4) tujuan: bertanya tentang penggunaan bentuk sapaan yang benar; (5) mitra tutur: ibu dan kakak; dan (6) situasi: santai, akrab.

Pada data tersebut, Dafa sedang berbincang-bincang tentang kereta api dengan ibunya. Di tengah-tengah pembicaraan berlangsung, Dafa mengalami kesulitan untuk menemukan istilah yang digunakan untuk menyebut orang yang mengemudikan kereta api. Untuk mengatasi kesulitan yang dihadapi Dafa secara langsung bertanya kepada mitra tuturnya dengan pertanyaan " $\mathrm{Pa}$ knya yang nyetir... apa namanya?". Pernyataan ini menunjukkan bahwa anak secara langsung meminta penajaman maksud tuturan yang diperlukan anak kepada mitra tuturnya. Dengan permintaan penajaman maksud tuturan secara langsung semacam ini anak dapat secara langsung memperoleh respon dari mitra tuturnya. Hal ini ditunjukkan dengan respon mitra tuturnya dengan memberikan jawaban, "Yang nyetir kereta? Masinis".

Permintaan penajaman maksud tuturan pada data tersebut diajukan karena anak mengalami kesulitan untuk menemukan kosakata yang tepat 
untuk menyatakan orang yang mengemudikan kereta api. Dengan cara ini anak tidak perlu berlama-lama berpikir atau mengingat-ingat istilah yang digunakan untuk menyebut orang yang mengemudikan kereta api tersebut. Keterlambatan anak memenuhi gilir tutur dapat mengganggu komunikasi karena membuat mitra tutur menunggu terlalu lama. Dengan cara ini anak secara langsung juga dapat memperoleh respon positif dari mitra tuturnya sehingga cara ini dapat mendukung pencapaian tujuan komunikasi yang diharapkan.

Penggunaan permintaan penajaman maksud tuturan pada data tersebut berfungsi untuk mengatasi kendala komunikasi karena ketidakberhasilan anak untuk mengingat atau menemukan kosakata untuk menyebut orang yang mengemudikan kereta api. Upaya anak ini terbukti dapat mendukung pencapaian tujuan komunikasi karena mitra tutur lang-sung memberikan jawaban yang diperlukan anak. Dengan demikian, anak dapat melanjutkan komunikasi dengan memanfaatkan penajaman maksud yang telah diberikan oleh mitra tuturnya. Hal tersebut tampak pada lanjutan tuturan anak yang berupa pertanyaan Pak masinisnya nggak bobok? Penggunaan kata pak masinis-nya pada pertanyaan tersebut menunjukkan bahwa anak telah memanfaatkan masukan bahasa yang baru diperolehnya. Hal ini membuktikan bahwa selain bermanfaat sebagai media untuk memperlancar komunikasi penggunaan bentuk strategi komunikasi ini bermanfaat sebagai media pengembangan kosakata. Menurut Leech (1983) penggunaan strategi komunikasi tertentu dalam sebuah percakapan pada umumnya memberikan efek positif bagi pembelajar karena memung-kinkan penutur dewasa dapat membatu pembelajar dalam menggunakan bentuk yang tepat untuk menyata- kan apa yang ingin disampaikan kepada mitra tutur.

\section{Bentuk Pemerolehan Praanggapan Anak Usia Prasekolah}

Praanggapan didasarkan pada pengetahuan prasyarat dari penutur dan mitra tutur. Praanggapan dapat dimiliki anak dan mitra tuturnya jika tuturan yang diujarkan mengandung komponen-komponen praanggapan pragmatik, yang meliputi (1) pernyataan yang tersirat atau terucap oleh penutur $(X)$, (2) praanggapan dari penutur dan mitra tutur (Y), (3) konteks yang melatarbelakangi komunikasi antara penutur dan mitra tutur (K), dan (4) maksud yang tersebunyi di balik pernyataan yang dikemukakan oleh penutur (Z). Perhatikan tuturan berikut ini.

Tuturan (4)

Karinda : Tasnya mbak Wardah tadi bagus ya?

Ibu : Iya. Kenapa, kamu pingin ya?

Konteks : (1) peristiwa tutur: Karinda berbincang-bincang dengan ibunya; (2) tempat: ruang keluarga; (3) waktu: siang hari; (4) tujuan: menyatakan keingingan dalam bentuk pernyataan; (5) mitra tutur: ibu; dan (6) situasi: santai, akrab.

Dialog tersebut memiliki komponen sebagai berikut (1) pernyataan yang tersirat atau terucap, yaitu Tasnya Mbak Wardah bagus ya?, (2) praanggapan penutur dan mitra tutur bahwa Wardah mempunyai tas dan ada tas yang bagus, (3) konteks yang melatarbelakangi komunikasi, konteks tas yang bagus, dan (4) maksud yang tersebunyi, meminta tanggapan terhadap pendapat tentang tas yang bagus dan ingin memiliki tas tersebut.

Penyusunan praanggapan dilakuan dengan penyusunan asserted dan presupposed. Asserted adalah pernyataan 
dalam bentuk kalimat atau ungkapan yang bersifat eksplisit, sedangkan presupposed, yaitu ide-ide implisit yang merupakan prasyarat atau yang terkandung dalam pernyataan. Praanggapan dapat diungkapan melalui pernyataan eksplisit dalam penyataan deklaratif dalam bentuk kalimat berita, pernyataan introgatif dalam bentuk kalimat tanya, dan pernyataan imperatif dalam bentuk kalimat perintah. Perhatikan contoh berikut.

Tuturan (5)

Nana : Ma, bonekaku mana?

Ibu : Boneka yang mana?

Nana : Yang baru, yang kelinci.

Konteks : (1) peristiwa tutur: Nana berbincang-bincang dengan ibunya; (2) tempat: ruang keluarga; (3) waktu: siang hari; (4) tujuan: menanyakan fakta tentang sesuatu yang telah diketahui bersama; (5) mitra tutur: ibu; dan (6) situasi: santai, akrab.

Asserted atau yang dinyatakan dalam kalimat tanya tersebut adalah pertanyaan mengenai tempat mainan (boneka) disimpan, mana maksudnya di mana sedangkan presupposed atau yang dipraanggapkan dalam tuturan tersebut adalah mitra tutur (ibu) tahu bahwa dia memiliki boneka kelinci dan tahu di mana boneka itu disimpan.

\section{Bentuk Pemerolehan Implikatur Anak Usia Prasekolah}

Lazimnya tuturan anak-anak berupa tuturan langsung, yaitu tuturan yang mempunyai lokusi harfiah. Namun, kadang-kadang tindak tutur yang diujarkan mempunyai dampak ilokusi yang berbeda. Sebagai contoh, tampak pada tuturan berikut ini.

Tuturan (6)

Karinda : Tasnya mbak Wardah tadi bagus ya?
Ibu : Iya. Kenapa, kamu pingin ya?

Karida : Aku belum punya tas Dora.

Konteks : (1) peristiwa tutur: Karinda berbincang-bincang dengan ibunya; (2) tempat: ruang keluarga; (3) waktu: siang hari; (4) tujuan: menyatakan keinginan dalam bentuk pertanyaan; (5) mitra tutur: ibu; dan (6) situasi: santai, akrab.

Tuturan Aku belum punya tas Dora sebenarnya hanyalah ujaran deklaratif semata. Akan tetapi, tuturan tersebut dapat dipahami sebagai permintaan, yang berimplikasi agar dia dibelikan tas tersebut. Contoh lain yang serupa tampak pada tuturan berikut.

Tuturan (7)

Karinda : Lapar, lapar. Aduh, perutku lapar!

Ibu : Beneran apa bohong, nanti gak dimakan?

Konteks : (1) peristiwa tutur: Karinda berbincang-bincang dengan ibunya; (2) tempat: ruang keluarga; (3) waktu: siang hari; (4) tujuan: menyatakan permintaan dalam bentuk pernyataan; (5) mitra tutur: ibu; dan (6) situasi: santai, akrab.

Tuturan Ma, lapar. Aduh, perutku lapar, dituturan Karinda dengan berteriak-teriak sambil memegang perutnya. Tuturan tersebut tentu bukan hanya merupakan pernyataan yang berisi informasi bahwa ia sedang lapar, tetapi merupakan permintaan anak kepada ibunya agar diambilkan makanan.

Makna implisit yang ada di balik apa yang dituturkan oleh anak ternyata cukup bervariasi. Berkenaan dengan hal ini Wiryotinoto (1996) mengemukakan bahwa implikatur percakapan tidak terlepas dari budaya menyampaikan suatu maksud secara terselubung atau secara 
tidak langsung demi kesopansantunan. Tampaknya, implikatur ini telah diterapkan anak sejak dini, baik untuk mengajukan permintaan, penolakan, maupun penyangkalan. Dengan berimplikatur anak berharap dapat mengkomunikasikan apa yang dimaksudkannya dan memperoleh tanggapan sebagaimana yang diimplikasikannya. Perhatikan contoh berikut.

Tuturan (8)

Desi : Ini Apa?

Ibu : Brem. Nggak usah makan Brem ya, nanti giginya sakit lagi.

Desi : Disinilo,nggaksakit (menunjuk gigi rahang bawah kiri).

Ibu : Jangan. Kalau sakit nanti ke dokter lagi.

Desi : Di sini lo, nggak sakit.

Konteks : (1) peristiwa tutur: Desi berbincang-bincang dengan ibunya; (2) tempat: ruang keluarga; (3) waktu: sore hari; (4) tujuan: menyatakan kenginan dalam bentuk pernyataan; (5) mitra tutur: ibu; dan (6) situasi: santai, akrab.

Pada tuturan tersebut anak menyangkal tuturan ibunya yang menyatakan bahwa dia sakit gigi, dengan menyatakan bahwa giginya sebelah kiri tidak sakit agar apa yang diimplikasikan dalam tuturan tersebut, yaitu permintaan agar boleh makan brem dipenuhi oleh ibunya. Hal ini dilakukan anak karena yang sakit adalah gigi rahang bagian kanan bawah dan ia merasa bisa menggunakan gigi rahang sebelah kiri bawah untuk mengunyah.

\section{Bentuk Pemerolehan Aturan Percaka- pan Anak Usia Prasekolah}

Bagi anak percakapan bukan merupakan hal yang asing karena sejak bayi, ibu dan juga anggota keluarga yang lain, selalu mengajak anaknya un- tuk bercakap-cakap meski percakapan tersebut terbatas pada percakapan satu arah. Kalau pun anak merespon tuturan orang dewasa, tentu responnya sebatas nonverbal, seperti senyuman, ocehan, atau jeritan.

Tuturan (9)

Ibu : Tadi di sekolah gimana, Nda? (yang dimaksud sekolah adalah TPQ).

Karinda : Aku tadi nggak diajar. Kakak marah sama aku. Aku nggak diajar.

Ibu : Lho kenapa, kamu jalan-jalan paling di kelas?

Karinda : Enggak. Mama ke sekolahku saja ya. Bilang sama Kak Ahmad, aku kok nggak diajar. Wis, sms saja. Kirim surat saja. Iya, kirim surat saja (Dia lalu pergi mengambil kertas dan pena, memberikan kepada ibunya)

Karinda : Ini mama yang nulis (meminta ibunya untuk menulis yang dia katanya). Minta maaf. Aku marah sama kamu karena anakku tidak kauajari. Aku akan marah terus kalau anakku tidak kamu ajari. Sudah Ma, mana? (meminta kembali kertas tersebut)

Ibu : Ini.

Karinda : (Melipat kertas) Wis, nanti takkirim ke Kak Ahmad, biar nanti baca.

Konteks : (1) peristiwa tutur: Sepulang sekolah Karinda berbincangbincang dengan ibunya; (2) tempat: ruang keluarga; (3) waktu: siang hari; (4) tujuan: menyatakan marah dengan dieksis kamu sebagai bentuk sapaan untuk gurunya; (5) mitra tutur: ibu; dan (6) situasi: santai, akrab. 
Percakapan tersebut terjadi setelah anak (Karinda) pulang dari belajar di TPQ. Sebagaimana lazimnya sebuah percakapan, percakapan tersebut menunjukkan adanya struktur percakapan yang lengkap, yaitu pembukaan, giliran bicara, dan penutup. Pembukaan percakapan terjadi secara lancar. Pembukaan percakapan yang dilakukan oleh orangtua langsung mendapat respon dari anak. Respon dari anak juga telah menunjukkan adanya relevansi tanggapan yang tepat. Anak juga telah menguasai aturan-aturan percakapan yang semestinya diikuti, yaitu anak menanggapi saat giliran bicaranya tiba, diam ketika mitra tuturnya menanggapi, dan mengambil kembali kesempatan giliran bicara, dan menutup percakapan dengan baik.

Pada kesempatan lain, anak berinisiatif untuk membuka percakapan. Pada percakapan berikut ini, anak membuka percakapan dengan pertanyaan.

Tuturan (11)

Karinda : Ma, selingkuh itu apa Ma? (Setelah selesai salat, tiba-tiba mengajukan pertanyaan tersebut).

Ibu : Kamu kok tanya gitu? Tahu dari mana Kamu?

Karinda : Dari TV. (Lalu menirukan dialog dalam sinetron yang pernah dia tonton di TV). Kamu selingkuh. Kamu yang selingkuh. Kamu. Kamu. Kamu.

Ibu : Selinguh itu ya, pokoknya berbuat yang tidak baik.

Konteks : (1) peristiwa tutur: Karinda berbincang-bincang dengan ibunya; (2) tempat: tempat salat; (3) waktu: malam hari; (4) tujuan: menanyakan fakta; (5) mitra tutur: ibu; dan (6) situasi: santai, akrab.

Inisiatif pembukaan percakapan dari anak didorong oleh rasa ingin tahu- nya mengenai hal yang didengarnya tetapi tidak dipahaminya, yakni berkaitan dengan suatu perkataan yang sebaiknya tidak diperdengarkan pada anak. Kata selingkuh tidak pernah didengar dalam percakapan sehari-hari sehingga ketika muncul di TV dia merasa asing dan menanyakan kata tersebut kepada orangtuanya. Giliran bicara juga berlangsung secara lancar, dan ditutup dengan penjelasan dari orangtua dengan tanggapan yang baik. Tampak anak merasa puas dengan jawaban orangtuanya sehingga dia tidak meminta penjelasan lagi. Ada kemungkinan anak kurang puas dengan jawaban orangtuanya tersebut karena sebelumnya orangtuanya menanggapi pertanyaan anak dengan pertanyaan balik yang menunjukkan keheranan dan ketidaksukaan dengan pertanyaan tersebut. Orangtuanya kemudian menjelaskan dengan singkat dan dinyatakan dengan nada yang menandai adanya permintaan agar percakapan berakhir yang ditunjukkan dengan ujaran dalam tempo yang lambat yang menandai penutupan percakapan sehingga percakapan telah dipandang cukup dan berakhir.

Dalam kehidupan sehari-hari percakapan singkat sering terjadi pada anak yang diawali dengan pertanyaan-pertanyaan mengenai banyak hal. Percakapan singkat berikut ini terjadi ketika anak melihat anak SD berbaris dengan menggunakan pakaian pramuka lengkap berbaris berjalan beriringan di jalan.

Tuturan (12)

Karinda : Pa, kalau sudah SD aku boleh pramuka? (melihat anak $\mathrm{SD}$ berbaris dengan memakai seragam pramuka).

Bapak : Boleh. Kamu suka ta Pramu$\mathrm{ka}$ ?

Karinda : Iya. Bawa Bendera.

Konteks : (1) peristiwa tutur: Karinda berbincang-bincang dengan 
bapaknya dalam perjalanan menjemput ibunya; (2) tempat: jalan raya; (3) waktu: siang hari; (4) tujuan: menyatakan keinginan dengan bentuk pertanyaan; (5) mitra tutur: bapaknya; dan (6) situasi: santai, akrab.

Meskipun singkat percakapan tersebut telah menggambarkan bahwa anak telah menguasai aturan percakapan dengan baik.

Percakapan anak juga telah menunjukkan adanya konstruksi yang memenuhi ciri-ciri tertentu berkaitan dengan interaksi sosial. Menurut Preston (1989), percakapan sebagai bentuk interaksi sosial mengandung tiga ciri, yaitu keurutan (sequentiality), konstruksi bersama (joint construction), dan kesalingtergantungan tindakan dan aktivitas (act-activity inter-dependence). Sebagai sebuah wacana, percakapan memiliki organisasi yang berurutan. Makna tiap ujaran dalam percakapan diperoleh berdasarkan kalimat sebelumnya, dan tiap peserta tutur mematuhi aturan keserasian pasangan kalimat sehingga terjadi kesinambungan antara kalimat yang satu dengan yang berikutnya. Konstruksi dan isi percakapan juga merupakan hasil kerja sama antarpeserta tutur. Hal ini ditunjukkan dengan keterkaitan antara kalimat yang satu dengan yang lain. Misalnya, kalimat kedua ditentukan oleh kalimat pertama, atau arah kalimat kedua ditentukan dari arah kalimat pertama. Antara peserta tutur yang satu dan yang lain saling bergantung sehingga suatu percakapan dapat berubah arah bila salah satu peserta tutur mengarahkan tuturannya dan ditanggapi oleh peserta tutur yang lain. Contoh beberapa percakapan tersebut menunjukkan bahwa rangkaian percakapan terangkai berdasarkan kalimat yang dituturkan sebelumnya.

\section{Bentuk Pemerolehan Inferensi Anak Usia Prasekolah}

Inferensi merupakan acuan dalam percakapan yang didasarkan pengetahuan dan pengalaman seseorang. Inferensi muncul sebagai akibat dari asosiasi atau rentetan dalam pikiran penutur terhadap sifat atau kebiasaan dari suatu objek pembicaraan.

Untuk memahami makna yang dimaksud penutur, tidak cukup bagi mitra tutur mengetahui makna literal dari kata-kata atau kalimat-kalimat yang dituturkan saja. Penutur dan mitra tutur harus menarik inferensi berdasarkan konteks komunikasi dan pengetahuan yang dimiliki mengenai apa yang dituturkan. Anak prasekolah berinferensi dalam berbagai cara, sebagai contoh tampak pada kutipan berikut ini.

Tuturan (13)

Ayah : Dik, nanti ikut lihat ekspo ya.

Nana : Aku nanti naik kuda-kudaan yang muter-muter itu ya Yah.

Konteks : (1) peristiwa tutur: Nana berbincang-bincang dengan bapaknya; (2) tempat: ruang keluarga; (3) waktu: siang hari; (4) tujuan: menyatakan fakta dengan dieksis kamu sebagai bentuk sapaan nenek; (5) mitra tutur: ibu dan nenek; dan (6) situasi: santai, akrab.

Di dalam tuturan tersebut anak (Nana) mengatakan Aku nanti naik kudakudaan yang muter-muter itu ya, Yah karena didasarkan inferensi bahwa di dalam ekspo (pameran) ada permainan kuda-kudaan atau berbagai binatang lain yang berputar-putar seperti yang dimaksud anak. Mirip dengan contoh tersebut tampak pada tuturan berikut ini.

Tuturan (14)

Ibu : Ibu ke Gramedia sebentar ya. Nana gakusah ikut, di rumah Embah saja. Kan ada Mbak 
Labda.

Nana : Lho, ikut. Aku mau buku cerita.

Ibu : Ibu kesusu, cuma sebentar. Kamu nanti mesti lama, pilih-pilih buku. Dimarahi yang jual nanti.

Nana : Sama Mbaknya i lo boleh, nggak marah.

Konteks : (1) peristiwa tutur: Nana berbincang-bincang dengan ibunya ketika ibunya akan pergi ke toko buku; (2) tempat: teras rumah; (3) waktu: siang hari; (4) tujuan: menyatakan keinginannya untuk ikiut ke toko buku; (5) mitra tutur: ibu; dan (6) situasi: santai, akrab.

Di dalam tuturan tersebut anak (Nana) mengatakan Lho, ikut. Aku mau buku cerita karena didasarkan inferensi bahwa di toko Gramedia ada buku, termasuk buku cerita. Dengan demikian, kalau dia ikut pergi ke Gramedia dia bisa minta dibelikan buku cerita. Hal ini tentunya berbeda kalau ibunya pergi ke pasar. Anak tidak akan minta dibelikan buku tetapi mungkin minta dibelikan sesuatu yang lain yang ditafsirkan bisa dibeli di pasar. Demikian halnya dengan kalimat Sama Mbaknya i lo boleh, nggak marah dituturkan karena adanya inferensi bahwa biasanya atau kebanyakan penjaga toko buku di Gramedia adalah wanita muda (meskipun ada beberapa yang laki-laki), sehingga dia menyebut penjaga toko tersebut dengan sapaan Mbaknya bukan Ibuknya atau Paknya.

\section{Simpulan}

Bentuk pemerolehan kompetensi pragmatik anak usia prasekolah terwujud dalam penggunaan aspek-aspek pragmatik yang ada dalam tuturan yang diproduksi anak dalam komunikasi sesuai dengan konteks penggunaannya. Penggunaan aspek-aspek pragmatik yang dimaksud adalah penggu-naan dieksis, praanggapan, implikatur percakapan, dan aturan percakapan.

Bentuk pemerolehan dieksis anak usia prasekolah tampak pada penggunaan dieksis berdasarkan tiga dimensi yang terlibat dalam suatu dieksis, yaitu temporal, spasial, dan sosial. Praanggapan dapat dimiliki anak dan mitra tuturnya jika tuturan yang diujarkan mengandung komponen-komponen praanggapan pragmatik, yang meliputi pernyataan yang tersirat, praanggapan dari penutur dan mitra tutur, konteks, dan maksud yang tersebunyi di balik pernyataan yang dikemukakan. Implikatur percakapan anak usia prasekolah tampak dalam bentuk tuturan langsung, yaitu tuturan yang mempunyai lokusi harfiah yang kadang-kadang mempunyai dampak ilokusi yang berbeda. Makna implisit yang ada di balik apa yang dituturkan oleh anak ternyata cukup bervariasi. Implikatur percakapan anak usia prasekolah tidak terlepas dari budaya menyampaikan suatu maksud secara terselubung atau secara tidak langsung demi kesopansantunan. Implikatur ini telah digunakan anak baik untuk mengajukan permintaan, penolakan, maupun penyangkalan. Dengan berimplikatur anak berharap dapat mengkomunikasikan apa yang dimaksudkannya dan memperoleh tanggapan sebagaimana yang diimplikasikannya. Percakapan anak usia prasekolah menunjukkan adanya struktur percakapan yang lengkap, yaitu pembukaan, giliran bicara, dan penutup. Anak juga telah menguasai aturan-aturan percakapan yang semestinya diikuti, yaitu anak menanggapi saat giliran bicaranya tiba, diam ketika mitra tuturnya menanggapi, dan mengambil kembali kesempatan giliran bicara, dan menutup percakapan dengan baik. Anak usia prasekolah berinferensi berdasarkan pikiran anak terhadap sifat atau kebiasaan dari objek 
yang dibicarakan.

Guru anak usia prasekolah di Taman Bermain atau Taman Kanak-kanak perlu memahami bahwa penguasaan kompetensi pragmatik anak bersumber pada pengalaman dan kesan yang diperoleh anak terhadap kondisi, tingkah laku, dan fenomena yang ada di sekitarnya yang dapat diamati secara konkret oleh anak. Hal tersebut dapat memaksimalkan perannya untuk menciptakan lingkungan belajar yang kondusif bagi perkembangan kompetensi pragmatik anak. Hal ini dapat dilakukan dengan cara melakukan penyesuaian-penyesuaian dalam rencara pembelajaran, memperhatikan kondisi siswa, fasilitas, dan media belajar bahasa, serta memaksimalkan pemberian kesempatan bagi anak untuk praktik ber-komunikasi.

\section{UCAPAN TERIMA KASIH}

Artikel ini diangkat dari penelitian mandiri swadana yang dilaksanakan pada tahun 2007. Ucapan terima kasih disampaikan kepada para mahasiswa yang telah membantu pelaksanaan pengumpulan data dan kepada mitra sejawat yang telah membantu kegiatan verifikasi dan triangulasi data dan hasil penelitian

\section{DAFTAR RUJUKAN}

Burt, M. dan Heidi, D. 1991. Optimal Language Learning Environment. Dalam James, E. Alantis (ed). The Second Language Classroom. Oxford: Oxford University Press.

Clark, E. V. 2003. First language Acquisition. New York: Cambridge University Press.

Dardjowidjojo. S. 1988. PELLBA I (Pertemuan Linguistik Lembaga bahasa Admajaya). Jakarta: Arcan.

Dardjowidjojo. S. 2000. ECHA Kisah Pemerolehan Bahasa Anak Indonesia. Jakarta: Grasindo.
Dardjowidjojo. S. 2003. Psikolinguistik: Pengantar Pemahaman Bahasa Manusia. Jakarta: Yayasan Obor Indonesia.

Hymes, D. 1972. On Communicative Competence. Dalam J.B. Pride dan J. Holmes (ed.), Sociolinguistics, Harmondsworth. Philadelphia: Univesity of Philadelphia Press.

Levinson, S. C. 1992. Pragmatics. Cambridge: University Press.

Leech, G. N. 1983. Principles of Pragmatics. London: Longman.

Littlejohn, S. W. 1992. Theories of Human Communication. $4^{\text {th }}$ Ed. California: Wadswortd Publishing Company.

Mey, Yacob L. 1993. Pragmatics an Introduction. Cambridge, Massachusetts: Blackwell Publisher Ltd.

Ninio, A. dan Catherine E. Snow. 1996. Pragmatic Development. USA: Wetsview Press, Inc.

Nababan, P. W. J. 1984. Sosiolinguistik. Jakarta: Gramedia.

Noremore R. C. dan Hoper, R. 1990. Children Learning Language. New York: Hoper \& Row Publisher.

Preston, D. 1989. Sociolinguistics and Language Acquisition. Oxford: Blackwell.

Sampson, 1983. Schools of Linguistics. London: Hutchinson.

Saville-Troike, M. 1986. The Ethnography of Communication. New York: Basil Blackwell Ltd.

Schiffrin, D. 1994. Approaches to Discourse Analysis. Cambridge: Blackwell Publisher.

Wiryotinoyo, M. 1996. Implikatur Percakapan Anak Usia SD. Disertasi tidak diterbitkan. Program Studi Pendidikan BI. PPS. IKIP MALANG. 